İş ve İnsan Dergisi I The Journal of Human and Work

Y1l | Year: Nisan | April 2021

Cilt-Sayı | Volume-Issue: 8 (1)

ss I pp: 73-90

doi: 10.18394/iid.732033

e-ISSN 2148-967X

http://dergipark.gov.tr/iid/

Araştırma Makalesi

\title{
Kadın Akademisyenlerin Sınırsız ve Çok Yönlü Kariyer Tutumlarının Kişilik Açısından İncelenmesi ${ }^{\mathrm{a}}$
}

\author{
The Investigation of Academic Women's Boundaryless and Protean Career Attitudes in \\ Terms of Personality
}

Esin Tarhan Överb, Müge Ersoy Kart ${ }^{\mathrm{c}}$

MAKALE BILGISII

\section{Anahtar Kelimeler:}

Sinırsiz Kariyer,

Çok Yönlü Kariyer,

Beș Faktör Kișilik Modeli

Kadin Akademisyenler,

Kariyer Tutumu.

Tarihler :

Geliş 4 Mayıs 2020

Düzeltme Geliş

11 Kasim 2020

Kabul 25 Kasım 2020

\begin{abstract}
ÖZ
Bu araştırmada, Ankara ilinde çalışan kadın akademisyenlerin sınırsız ve çok yönlü kariyer tutumlar, kişilik özellikleri açısından incelenmektedir. Bu amaç çerçevesinde kamuda ve özel sektörde çalışan 306 kadın akademisyene kişisel bilgi formu, sinırsız ve çok yönlü kariyer ölçeği ve bes faktör kișilik envanteri uygulanmıștır. Korelasyon analizi bulgularına göre kişilik boyutları (nevrotiklik, uzlaşılabilirlik, özdisiplin, dişadönüklük, deneyime açıllı) ile sınırsız ve çok yönlü kariyer tutumları arasında zayıf ya da orta düzeyde iliskiler saptanmıștır. Kadın akademisyenlerin deneyime açılklk ve dışadönüklük özellikleri arttıkça psikolojik hareketlilik düzeylerinin de arttı̆̆l, ancak fiziksel kariyer hareketlerinin azaldlğg tespit edilmişstir. Regresyon analizi sonucunda deneyime açıklık ve özdisiplin özelliklerinin çok yönlü kariyer tutumunu pozitif yönde, nevrotiklik özelliğinin negatif yönde yordadlğı ortaya çıkmıştır. Dışadönüklük özelliği ise sınırsız kariyer tutumunu pozitif yönde yordamaktadır. Araştırmadaki bulgular, önceki çalışmalar ve kuramsal yaklaşımlar çerçevesinde tartışılmıştır. Elde edilen sonuçlar, kadınların kariyer kararlarını etkileyen kişilik değiş̧kenlerini ortaya çıkarmak bakımından önem taşımaktadır.
\end{abstract}

\section{A R T ICLE INFO}

Keywords:

Boundaryless Career,

Protean Career,

Five Factor Personality

Model, Academic Women,

Career Attitude.

Article history:

Received 4 May 2020

Received in Revised Form

17 November 2020

Accepted 25 Kasım 2020

\begin{abstract}
A B S T R A C T
This study focuses on boundaryless and protean career attitudes of academic women in Ankara, in terms of personality traits. For this purpose, personal information form, boundaryless and protean career attitudes scale, five factor personality inventory were applied to 306 women working in public and private universities. Correlation analyses show that there are small to moderate relationships between personality traits (extroversion, openness to experience, agreeableness, conscientiousness, neuroticism) and boundaryless/protean career attitudes. Findings indicate that, psychological mobility increases and physical mobility decreases, as women's level of openness to experience and extroversion increases. Regression analyses show that openness to experience and conscientiousness have a positive effect and neuroticism has a negative effect on protean career attitude. Extroversion, on the other hand, has a positive effect on boundaryless career attitude. Findings mentioned above were discussed in line with previous research. Results are noteworthy in terms of discovering personality traits that predict women's career decisions.
\end{abstract}

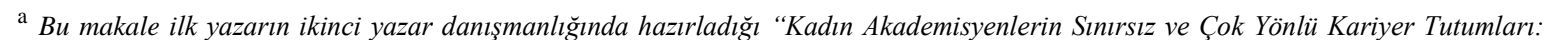
Kişilik ve Toplumsal Cinsiyet Rolleri Açısından Bir İnceleme” başlıklı doktora tezinden (Ankara Üniversitesi, Sosyal Bilimler Enstitüsü, 2019) üretilmiştir.

b İletişim kurulacak yazar, Dr., Yarl Zamanlı Öğretim Görevlisi, TED Üniversitesi, Fen Edebiyat Fakültesi, Ankara, Türkiye. esin.tarhan@tedu.edu.tr.ORCID: 0000-0002-4764-7560.

c Prof. Dr., Ankara Üniversitesi, Siyasal Bilgiler Fakültesi, Ankara, Türkiye. ersoy@politics.ankara.edu.tr. ORCID: 0000-0003-41041645.
} 


\section{GİRIŞ}

Kariyer, hiç kuşkusuz bireyin yaşamındaki en önemli parçalardan biridir. Özellikle sanayi devrimi sonrasında çalışma biçiminde meydana gelen köklü değişiklikler, insanların yepyeni çalışma modelleri ile tanışmalarına neden olmuştur. Zaman içinde meydana gelen teknolojik gelişmeler ve küreselleşme, kariyer olgusunu bambaşka bir noktaya taşımıştır. Kısa bir süre öncesine kadar insanların ilk iş yerlerinden emekli olmaları çok sık rastlanan bir durum iken, günümüzde insanların, özellikle de özel sektör çalışanlarının sık sık iş değiştirdikleri gözlemlenmektedir. $\mathrm{Bu}$ açıdan bakıldığında geleneksel kariyer örüntüsü yerini yeni (modern) kariyer modellerine birakmaya başlamıştır.

"Sınırsız kariyer" (Arthur, 1994; Arthur ve Rousseau, 1996) ve “Çok yönlü kariyer” (Hall, 1976, 1996) olarak adlandırılan yeni yaklaşımlar, geleneksel kariyerden birçok yönüyle ayrılmaktadır. "Tek bir örgütle sınırlı olmayan kariyer" anlamına gelen sınırsız kariyer, "fiziksel” ve "psikolojik" hareketliliği içeren bir tutum içinde olmayı gerektirmektedir (Sullivan ve Arthur, 2006). Bu tutum içindeki birey, tüm yaşamı boyunca tek bir yere bağlı olarak çalışıp oradan emekli olmaktansa yaşam önceliklerine göre iş yeri, sektör, meslek değiştirmekte, iş hayatına bir süre ara vermekte, yarı zamanlı ya da proje bazlı çalışmayı tercih etmekte veya buna benzer başka kararlar almaktadır. Çok yönlü kariyer ise bireyin "değerlerine göre hareket etme" ve "kendi kendini yönetme” tutumlarından oluşmaktadır (Briscoe ve Hall, 2006). Çok yönlü kariyerde, geleneksel kariyerde olduğu gibi tüm kariyer gelişimini çalıştı̆̆ örgüte bağlayan ve bir bakıma pasif olmayı seçen birey yerine, örgüt içinde ya da dışında çeşitli gelişim firsatlarını kovalayan ve kariyeriyle ilgili sorumluluk almaya hazır bir birey söz konusudur. Sonuç olarak yeni kariyer modelleri bireyin kendi değerlerine, değişen yaşam önceliklerine göre karar vermesini ve kariyeri üzerinde daha aktif bir rol üstlenmesini gerektirmektedir. Değişen kariyer paradigmalarının, bu araştırmanın odağını oluşturan kadın akademisyenlerin iş yaşamını da etkilediği düşünülmektedir.

Yeni kariyer yaklaşımları ile birlikte araştırmanın önemli bir inceleme konusu da kişilik boyutlarıdır. Kişilik, başta psikoloji alanında çalışan bilim insanları olmak üzere pek çok araştırmacının odaklandığı bir konudur. Özellikle son yıllarda kariyer yaşamına ilişkin farklı konular (performans, iş doyumu, bağlılık...) kişilik özellikleri ile açıklanmaya çalışılmaktadır (Barrick ve Mount, 1991; Choi, Oh ve Colbert, 2015; Judge ve Ilies, 2002; Salgado, 1997; Wille, De Fruyt ve Feys, 2010; Zimmerman, 2008). "Beş Faktör Kişilik Modeli”nde nevrotiklik, dişadönüklük, uzlaşılabilirlik, deneyime açıklık ve özdisiplin olmak üzere beş farklı kişilik boyutu bulunmaktadır (McCrae ve John, 1992). Çalışmamızda da, sınırsız ve çok yönlü kariyer yaklaşımları bu kişilik boyutları açısından ele alınmakta, bu sayede kadın akademisyenlerin kişilik özellikleri ve kariyer tutumları arasındaki ilişkinin keşfedilmesi amaçlanmaktadır.

\section{KAVRAMSAL ÇERÇEVE}

\subsection{Sinırsız Kariyer}

Sınırsız kariyer "tek bir örgütün sınırlarını aşan iş olanakları dizisi" şeklinde tanımlanmaktadır (Arthur, 1994; DeFillippi ve Arthur, 1994). Sınırsız kariyer kavramının içinde yer alan "sınır" kelimesi, bireyin sabit bir meslek, pozisyon, çalışma biçimi veya örgüt ile sınırlı olmadığını ifade etmek üzere kullanılmaktadır. Çalışanlar artık yaşam boyu tek bir örgütle ve tek bir pozisyonla kısıtlanmış değillerdir. Arthur (1994) sınırsız kariyer kavramını altı şekilde detaylandırmaktadır:

1. Farklı işverenlerin sınırlarını aşan hareketlilik (Örneğin Silikon Vadisi çalışanları),

2. Mevcut örgüt dışında da pazarlanabilir ve geçerli olma (Akademisyenlik),

3. Dışsal bağlantı (network) ve bilgi kaynaklarının sürdürülmesi,

4. Örgütlerin sunduğu geleneksel hiyerarşi ve kariyer gelişimi kalıplarını kırma,

5. Kişisel ve ailesel nedenlerle mevcut kariyer imkanlarını reddetme,

6. Yapısal kısıtlamalara rağmen sınırsız bir gelecek algisına sahip olma.

Sullivan ve Arthur (2006) sınırsız kariyerin daha iyi anlaşılması ve araştırılması için iki ayrı boyut tanımlamışlardır. Buna göre sınırsız kariyer, fiziksel hareketlilik (physical mobility) ve psikolojik hareketlilik (psychological mobility) olarak iki boyut içermektedir. Fiziksel hareketlilik çalışanın eyleme geçerek farklı işlere, örgütlere ya da sektörlere fiilen geçiş yapması olarak nitelendirilebilir. Bir başka deyişle fiziksel hareketlilik, bireyin sınırları aşarak hareket etmesi ve kariyerinde somut değişiklikler yapmasıdır. Psikolojik hareketlilik ise kişinin bu geçişi yapabilme kapasitesine ilişkin algısı olarak tanımlanmaktadır. Birey, iş çevresinde zenginlikçeşitlilik arzulamakta ve bunu gerçekleştirebilme 
becerisine sahip olduğuna dair kendine güvenmektedir (Sullivan ve Arthur, 2006). Çalışanlar iş yerlerinden fiziken ayrılmamış olsa bile psikolojik hareketliliğe sahip olabilmektedirler.

Sınırsız kariyerin geleneksel kariyere göre daha kısa süreli, belirsiz ve değişken olduğu bilinmektedir. Proje bazlı, yarı zamanlı, serbest veya esnek çalışma modelleri sınırsız kariyer içinde yer almaktadır. Günümüzde bazı bireylerin geleneksel kariyer yerine bu tür modelleri tercih ettiği bilinmektedir. Bazı bireyler için sınırsız kariyer bir tercih iken, diğerleri için iş kaybı, rütbe indirme gibi durumlar nedeniyle bir mecburiyet olabilmektedir (Sullivan, 1999). Bireyler kimi zaman zorunda kaldıkları için iş yaşamına ara vermekte ya da başka iș bulamadıkları için proje bazlı işlere yönelebilmektedirler. Dolayısıyla sınırsız kariyerin gönüllü ya da gönülsüz olarak gerçekleşmesi mümkündür. Araştırmalar kadınların daha çok iş değiştirdiklerini (Valcour ve Tolbert, 2003), kariyerlerine kimi zaman ara verdiklerini (Cabrera, 2007), çalışma saatlerini azalttıklarını (Bianchi, Robinson ve Milkie, 2006; Mainiero ve Sullivan, 2005), yarı zamanlı (part-time) çalışanların çoğunun kadın olduğunu ve bu nedenle kesintili/parçalanmış (fragmented) kariyerlere sahip olduklarını (Biemann, Zacher ve Feldman, 2012) ortaya koymaktadır. Bu da kadınların sınırsız kariyerin "fiziksel hareketlilik" boyutunda erkeklerden daha aktif olduklarını göstermektedir.

\section{2. Çok Yönlü Kariyer}

Geleneksel kariyerin yerini aldığı ifade edilen yeni kariyer yaklaşımlarından biri de çok yönlü (protean) kariyerdir. İlk defa 1976 yılında Hall tarafindan ortaya atılan, ancak o dönemde yeterince ilgi çekmeyen; yirmi yıl sonra yine Hall (1996) tarafindan yayınlanan makale ile yoğun biçimde tartışılmaya başlanan çok yönlü kariyer kavramı, adını Yunan tanrısı Proteus'tan almaktadır. Bu tanrının en önemli özelliği, istediği zaman şekil değiştirmesidir. Protean kelimesi İngilizce-Türkçe sözlüklerde “değişken” ve “çok yönlü” olarak çevrilmektedir. Modeli konu alan Türkçe çalışmaların çoğunda da (Kale ve Özer, 2012; Onay ve Vezneli, 2012; Paksoy, Hırlak ve Balıkçı, 2017; Suvacı ve Baş 2018) protean kelimesi, “çok yönlü” biçiminde kullanılmıştır. Bununla birlikte Seymen (2004) "dinamik/değişken", Çakmak-Otluoğlu (2018) ise "bağımsız" kelimesini tercih etmiştir. Aslında kelimenin anlamına en uygun çevirinin Çakmak-Otluoğlu'nun (2018) belirttiği gibi "bağımsız" olduğu anlaşılmaktadır. Çünkü protean kariyerde, izleyen bölümde de aktarılacağı gibi kendi kendini yönetme ve örgütten bağımsız hareket edebilme gibi özellikler vurgulanmaktadır. Bununla birlikte mevcut alanyazın ile dil birliği ve kavram bütünlüğü sağlamak adına bu çalıșmada da protean kelimesinin karşılığı olarak "çok yönlü” ifadesinin kullanılması uygun görülmüştür.

Hall (1976, 1996) çok yönlü kariyeri tanımlarken "gelişim ve özgürlük ihtiyacının ön planda olduğu, bireyin kariyerini kendisinin yönettiği, hareketlilik seviyesinin yüksek olduğu, örgüt tarafından değil, birey tarafından şekillendirilen, zaman içinde birey ve çevre değiştikçe yeniden oluşturulan kariyer" ifadelerini kullanmıştır. Briscoe ve Hall (2006), çok yönlü kariyerin iki boyutunu "kendi kendini yönetme" ve "değerlerine göre hareket etme" olarak adlandırmıştır. Kendi kendini yönetme, bireyin kendi kariyerini yönetirken örgütten bağımsız bir rol üstlenmesini ifade etmektedir. Geleneksel kariyerde bunun tam tersi söz konusudur. Birey kariyer ve mesleki gelişim ile ilgili tüm konuları örgütün inisiyatifine bırakmaktadır. Oysa kendi kendini yöneten birey, örgütün yönlendirmesini beklemeden seçimlerini kendisi yapacak ve kariyer gelişiminden bizzat kendisi sorumlu olacaktır. Değerlerine göre hareket etme ise, örgüt yapısının sunduğu değerler yerine kendi değerlerini ön plana almayı ifade etmektedir. Çok yönlü kariyerde bireyin kariyer başarısı daha çok subjektif ve psikolojik ölçütlere göre şekillenmektedir (Hall, 1976, 2004). Değerlerine göre hareket eden birey iş tatmini, gelişim, iş-yaşam dengesini kurma gibi içsel faktörlerle güdülenmekte; maaş, terfi, iş güvencesi gibi dışsal başarı kriterlerinden daha az etkilenmektedir (Segers, Inceoglu, Vloeberghs, Bartram ve Henderickx, 2008). Çok yönlü kariyer yönelimi ile kariyer ve iş tatmini arasında pozitif yönde bir ilişki bulunmaktadır (Baruch, 2014). Bununla birlikte yeni kariyer modellerinde yüksek düzeyde özdisiplin gerekmektedir çünkü çalışanlar örgüte bağımlı olmadan sağlık, sosyal güvenlik ve emeklilik gibi haklarını kendileri düşünerek planlamak zorundadırlar (Sullivan, 1999).

\subsection{Beş Faktör Kişilik Modeli}

Kişilik özelliği (trait), kişiliğin sürekli ve tutarlı olarak sergilenen yanlarını tanımlamak üzere verilen etiketlere denmektedir (Houston, 2005). "Özellik", kişiliği oluşturan temel yapı taşıdır ve insanların düşünme, hissetme ve davranma biçimindeki sabit kalıplar olarak tanımlanabilir (Pervin, Cervone ve John, 2005). Ayırıcı özellik, bireyin belirli bir kişilik özelliğini ne derece gösterdiğine göre kişiyi sınıflandıran bir kişilik yaklaşımıdır (Burger, 2006). Ayırıcı özellik kuramları, insanların davranışları altında yatan sebepleri bulmaya çalışmaktan ziyade, kişiliği tanımlamaya ve davranışları anlamaya odaklanmaktadır. 
Ayırıcı özellik kuramları içinde en çok kullanılan model, "Beş Faktör Kişilik Modeli"dir (FFM: Five factor model of personality). Beş faktör kişilik modelinin ortaya konmasında pek çok araştırmacının payı bulunmaktadır. Bununla birlikte, model günümüzde Robert McCrae, Paul Costa ve Oliver P. John ile özdeşleşmektedir. Kişilik ile ilgili geçmişte yapılan çalışmalara McCrae, Costa ve John'un araştırmaları (McCrae ve Costa, 1987, 1989, 1997, 1999; Costa ve McCrae, 1992a, 1992b; McCrae ve John, 1992) eklenmiş; beş faktör kişilik modeli bugünkü halini almıştır. Beş faktör kişilik modeli, kişilik özelliklerinin beş boyutta hiyerarşik bir şekilde örgütlenmesidir. Modelde beş ana faktör altında toplanan çok sayıda özellik tanımlanmaktadır (McCrae ve John, 1992):

- Dlşadönüklük: Dişadönüklük, en yalın biçimiyle bireyin sosyal durumlara yaklaşma biçimi olarak tanımlanabilir (Wolff ve Kim, 2012). Dişadönük bireyler içedönük bireylerle kıyaslandığında daha girişken, aktif ve dürtülerine göre hareket eden bir yapıya sahiptirler. Costa ve McCrae (1992b), dışadönüklüğün alt boyutlarını sıcakkanlılık, girişkenlik, kendine güven duyma, atak olma, heyecan arama ve olumlu duygulanım olarak belirtmiştir. Leong ve Boyle (1997) dışadönük erkeklerin daha sık iş değiştirdiklerini, buna karşın kadınlar için durumun tam tersi olduğunu ifade etmiştir.

- Nevrotiklik / Duygusal Denge: Düşük duygusal denge ya da yüksek nevrotiklik düzeyi, bireyin kayg1, depresyon, öfke, anlık değişen ruh hali gibi olumsuz duygular içinde olmasını ifade etmektedir (Weisberg, DeYoung ve Hirsh, 2011). Duygusal dengeye sahip olmayan (nevrotik) bireyler karşılaştıkları durumlara karşı kendilerini olumlu biçimde ayarlama becerisinden yoksundurlar (Brown ve Hirschi, 2013). Nevrotiklik ile kariyer kararı verme zorluğu yaşama arasında pozitif bir ilişki bulunmaktadır (Hirschi, Niles ve Akos, 2011; Martincin ve Stead, 2015). Nevrotiklik iş tatmini ile negatif yönde ilişkilidir (Bruk-Lee, Khoury, Nixon, Goh ve Spector, 2009; Judge ve Ilies, 2002) ve duygusal denge düzeyi çalışanların işten ayrılma niyetini en güçlü biçimde yordayan faktördür (Cropanzano, James ve Konovsky, 1993; Zimmerman, 2008).

- Özdisiplin: Özdisiplin birbirleriyle bağlantılı üç değişik boyutla ilişkilendirilmektedir. Bunlar başarı odaklılık (çalışkan ve ısrarcı olma), güvenilirlik (sorumluluk sahibi ve dikkatli olma) ve düzenlilik (planlı ve organize olma) olarak sıralanabilir (Judge, Higgins, Thoresen ve Barrick, 1999). Özdisiplin düzeyi yüksek kişilerin etkili problem çözme becerisine sahip oldukları, gerektiğinde çevrelerinden destek aradıkları, bilişsel yapılandırma (olumlu düşünme) yolu ile başa çıkma becerilerini kullandıkları savunulmaktadır (ConnorSmith ve Flachsbart, 2007). Özdisiplinli insanların daha fazla performans sergiledikleri (Barrick ve Mount, 1991), daha fazla iş doyumuna sahip oldukları (Sutin, Costa, Miech ve Eaton, 2009) kariyerlerinin daha başarılı biçimde geliştiği (Katic, Ivanisevic, Grubic-Nesic ve Penezić, 2017), daha uzun süre şirkette kaldıkları (Robbins ve Judge, 2013) ve özdisiplin düzeyi düşük bireylerin işlerinden fiilen daha çok ayrıldıkları (Zimmerman, 2008) tespit edilmiştir.

- $\quad$ Deneyime Açıklık: Bu kişilik özelliği güçlü bir hayal gücü, farklı fikirlere açık olma isteği, çok yönlü düşünebilme ve zihinsel merak gibi alt boyutlara sahiptir (Burger, 2006). Deneyime açık olan bireyler, yaratıcı, meraklı, esnek, orijinal ve özgür düşünebilen, açık fikirli, sanat anlayışına ve estetik değerlere sahip ve kendilerini çoğu zaman toplum kurallarına uzak gören bir yapıya sahiptirler (Costa ve McCrae, 1992b). Yapılan araştırmalar, dişadönük bireylerin hem işlerinden daha fazla doyum sağladıklarını (Judge, Heller ve Mount, 2002) hem de kendilerini daha mutlu hissettiklerini (DeNeve ve Cooper, 1998) göstermektedir. Deneyime açık bireylerin kariyer yaşamlarında farklı alternatifleri değerlendirmeyi sevdikleri, ilerleyip statü kazanmayı hedefledikleri ve mevcut iş yerlerinden ayrılmayı göze aldıkları tespit edilmiştir (Choi, Oh ve Colbert, 2015; Dragoni, Oh, Vankatwyk ve Tesluk, 2011; Hogan ve Holland, 2003).

- Uzlaşılabilirlik: Uzlaşabilirlik çoğunlukla kibarlık, esneklik, güvenilirlik, işbirliğine yatkınlık, bağışlayıcılık, yumuşak kalplilik ve hoşgörülü olma ile tanımlanmaktadır (Barrick ve Mount, 1991). Uzlaşılabilirlik özelliği yüksek bireylerin takım çalışmasına daha yatkın oldukları ve diğer insanlarla iyi arkadaşlık ilişkileri kurdukları bilinmektedir (McCrae ve John, 1992). Uzlaşılabilirlik özelliğinin güçlü bir performans yordayıcısı olmadığı (Rothmann ve Coetzer, 2003; Salgado, 1997) ve uzlaşılabilirlik düzeyi düşük bireylerin iş yerlerinden daha sık ayrıldıkları (Wille, De Fruyt ve Feys, 2010) bulunmuştur.

Literatürde beş faktör kişilik özellikleri ile sınırsız ve çok yönlü kariyer yaklaşımlarını birlikte inceleyen bir çalışmaya rastlanmamıştır. Ancak yukarıda bahsi geçen araştırma sonuçları, yeni kariyer yaklaşımları içinde yer alan pek çok konunun (kariyer değişikliği, işten ayrılma, iş doyumu, motivasyon...) kişiliğin boyutlarıyla ilişkili olduğunu ortaya koymaktadır. 


\section{YÖNTEM}

\subsection{Araştırmanın Amacı ve Önemi}

Kadınların kariyer kararları pek çok karmaşık faktörden etkilenmektedir. Kariyer alanında yapılan çalışmalar, kadınların iş yaşamında karşılaştıkları engeller, ayrımcılık, fırsat eşitsizliğgi, ataerkil aile yapısı, çocuk ve yaşlı bakımı gibi nedenlerle erkeklerden daha farklı bir kariyer örüntüsüne sahip olduklarını ortaya koymaktadır. Bununla birlikte kadınların kariyer kararlarını etkileyen faktörlerin sadece ekonomik, çevresel ya da kültürel açılardan incelenmesi yeterli olmamakta, araştırmaların psikolojik boyutları ele alması gerektiği de vurgulanmaktadır. Sullivan ve Arthur (2006) kariyer tutumlarında kișilik değișkeninin, özellikle "Beş Faktör" boyutlarının incelenmesinin önemine değinmiştir.

$\mathrm{Bu}$ araștırmanın amacı, beş faktör kișilik özelliklerinin (dișadönüklük, özdisiplin, uzlaşılabilirlik, nevrotiklik ve deneyime açıklık) Türkiye'deki kadın akademisyenlerin sınırsız ve çok yönlü kariyer tutumlarını ne şekilde açıkladığını ortaya koymaktır. Araştırmanın odağını oluşturan kadın akademisyenlerin özel bir çalışan grubu olduğu bilinmektedir. Baruch ve Hall (2004) akademisyenliğin geleneksel çalışma saatleri ile sınırlı olmadığını ve sadece iş yerini kapsamadığını vurgulamaktadır. Kadın akademisyenler, iş dıșındaki zamanlarda da bilimsel faaliyetler ile ilgilenmek zorunda kaldıklarından çeşitli rol çatışmaları yaşamaktadırlar (Özkanlı ve Korkmaz, 2000). Sunulan çalışma, kadın akademisyenlerin kariyerlerinde meydana gelen değişiklikleri anlamak ve kariyer kararlarını yordayan farklı değişkenleri ortaya çıkarmak bakımından önem taşımaktadır. Kariyer olgusunun ve kadın istihdamının giderek önem kazandığı günümüzde, bu konuda yapılacak bir araştırmanın önemli katkılar sağlayacağı ve farklı çalışmalara öncülük edeceği düşünülmektedir.

\subsection{Araștırma Soruları}

Araştırmamızda kadın akademisyenlerin kariyer tutumları ve kişilik özellikleri araştırılmış ve aşağıdaki araştırma sorularına yanıt aranmıştır:

Araştırma Sorusu 1: Kadın akademisyenlerin çok yönlü ve sınırsız kariyer tutumları ile kişilik özellikleri arasında ilişki var mıdır?

Araştırma Sorusu 2: Kadın akademisyenlerin çok yönlü ve sınırsız kariyer tutumları ile demografik değişkenler (yaş, son iş yerindeki çalışma süresi, çalışma hayatındaki toplam deneyim yılı) arasında ilişki var mıdır?
Araștırma Sorusu 3: Kadın akademisyenlerin çok yönlü ve sınırsız kariyer tutumlarını yordayan kişilik özellikleri nelerdir?

\subsection{Calıșma Grubu}

$\mathrm{Bu}$ araştırmanın çalışma grubunu, Ankara'daki üç devlet ve üç vakıf üniversitesinde profesör, doçent, dr. öğretim üyesi, okutman ve öğretim görevlisi olan 22-65 yaş arası toplam 306 kadın akademisyen oluşturmaktadır. Araştırmada yer alan gruplar seçkisiz örnekleme yöntemlerinden basit seçkisiz örnekleme kullanılarak seçilmiştir.

Katılımcıların \%51,3'ü özel sektörde, \%48,7'si ise kamu sektöründe çalışmaktadır. Özel üniversitelerde çalışan kadın akademisyenlerin $\% 58,6$ 'sının 35 yaş altında ve \%9,6'sının 46 yaş üstünde olduğu görülmektedir. Kamu üniversitelerinde ise bu oran sirasiyla $\% 27,5$ ve $\% 25,5$ olarak gerçekleşmektedir. Son iș yerindeki çalışma sürelerine bakıldığında 3 yıl ve daha az çalışanlar özel sektörde \%51 iken kamu sektöründe \%18,1'dir. 16 yıldan uzun süredir çalışanların oranı ise özel sektörde \%4,5; kamu sektöründe \%38,9 olarak tespit edilmiştir. Çalışma hayatındaki toplam süreleri incelendiğinde özel üniversitelerdeki kadın akademisyenlerin \%29,3’ünün; kamu üniversitelerindeki kadın akademisyenlerin ise sadece \%6'sının 5 yıl ve daha kısa süredir çalıștığı görülmektedir. Bununla birlikte özel sektörde çalışan kadın akademisyenlerin \%8,3'ü; kamu sektöründe çalıșan kadın akademisyenlerin de \%30,9'u 21 yıl ve üzeri deneyime sahiptir. Kaçıncı iş yerlerinde çalıştıkları sorusuna birinci ya da ikinci olarak yanıt veren katılımcıların oranı özel sektörde \%43,3 iken kamu sektöründe \%75,2'dir. Altı ve üzeri iş yerinde çalışanlar özel sektörde $\% 5,7$; kamu sektöründe ise $\% 2$ olarak bulunmuştur. Eğitim seviyesine göre özel sektördeki katılımcıların \%38,2'si lisans, \%39,5'i yüksek lisans ve \%22,3’ü ise doktora derecesine sahiptir. $\mathrm{Bu}$ oran kamu sektöründe çalışan kadın akademisyenler için sirasıyla \%12,8; \%16,1 ve \%71,1'i olarak bulunmuştur. Medeni durum incelendiğinde, tüm katılımcıların \%63,7'si evli, $\% 36,3$ 'ü ise bekardır.

\subsection{Veri Toplama Araçları}

Araştırma kapsamındaki veriler Eylül 2018 - Ocak 2019 tarihleri arasında toplanmıştır. Ölçeklerin bulunduğu sayfanın linki e-posta yoluyla kadın akademisyenlere iletilmiş; katılımcıların online olarak verdikleri cevaplar Google forms programıyla kayıt altına alınmıştır.

Araştırmayla ilişkili olabilecek çeşitli bilgileri elde etmek ve demografik özelliklerini anlamak amacıyla kadın akademisyenlerden yaş, çalışılan 
sektör (kamu - özel), medeni hal, iş yerindeki kıdem süresi gibi çeşitli sorular içeren Kişisel Bilgi Formu'nu doldurmaları istenmiştir.

Katılımcıların kariyer tutumlarını ölçmek amacıyla Briscoe, Hall ve DeMuth'un (2006) oluşturduğu "Sınırsız ve Çok Yönlü Kariyer Tutumları Ölçeği”nin Kale ve Özer (2012) tarafından gerçekleştirilen Türkçe uyarlaması kullanılmıştır. Ölçek, çok yönlü ve sınırsız kariyer tutumlarını ayrı ayrı ölçmeyi hedefleyen iki soru setinden ve toplam 26 sorudan oluşmaktadır. Ölçekte "İşletmem emeklilik yaşına gelinceye kadar beni istihdam etse, asla başka bir iş aramam"(sınırsız kariyer) ve "Kariyer tercihlerimle ilgili olarak başkalarının fikirleri beni etkilemez” (çok yönlü kariyer) gibi ifadeler yer almaktadır. Katılımcılardan, kendilerine uygun olan seçeneği beşli Likert tipi ölçek (1: hiçbir zaman, 5: her zaman) üzerinde işaretlemeleri istenmiştir. Çok yönlü kariyer ölçeğinin güvenilirliği Cronbach Alpha=0,8426, sınırsız kariyer ölçeğinin güvenilirliği Cronbach Alpha=0,8261 olarak bulunmuştur (Kale ve Özer, 2012). Ölçeklerin bu çalışma kapsamındaki geçerlilik ve güvenirlik analizleri aşağıda yer almaktadir.

Tablo 1: Çok Yönlü Kariyer Tutumu için KMO ve Bartlett Testi Sonuçları

\begin{tabular}{llr}
\hline $\begin{array}{l}\text { Kaiser-Meyer-Olkin (KMO) Örneklem Ölçüm } \\
\text { Değer Yeterliliği }\end{array}$ &, 885 \\
\hline \multirow{2}{*}{ Bartlett Küresellik Testi } & Ki-Kare & 1701,753 \\
& df & 78 \\
& Sig. &, 000 \\
\hline
\end{tabular}

Tablo 1'de görüldüğü üzere, Çok Yönlü Kariyer Tutumu için yapılan faktör analizinde KMO değeri 0,885 olarak hesaplanmıştır. Buna göre örneklem sayısı faktör analizi için uygundur (KMO>0,500).
Bartlett testi kapsamında 1701,753 olarak hesaplanan X2 değeri istatistiksel açıdan anlamlı bulunmuştur $(p<0,05)$. KMO ve Bartlett testi sonucuna göre verilerin faktör analizi için uygun olduğu sonucuna ulaşılmıştır. Çok Yönlü Kariyer Tutumu için faktör analizi sonuçları Tablo 2'de yer almaktadır.

Analiz sonuçlarına göre Çok Yönlü Kariyer Ölçeği'ndeki maddelerin orjinaliyle aynı faktör dağılımına sahip olduğu anlaşılmıştır. Çok yönlü kariyer tutumunun iki boyutu toplam varyansın yüzde 53,66’sını açıklamaktadır. Cronbach Alfa güvenirlik katsayıları ise Değerlerine Göre Hareket Etme için 0,822 ve Kendi Kendini Yönetme için 0,839 olarak bulunmuştur.

Tablo 3: Sınırsız Kariyer Tutumu için KMO ve Bartlett Testi Sonuçları

\begin{tabular}{llr}
\hline $\begin{array}{l}\text { Kaiser-Meyer-Olkin (KMO) Örneklem } \\
\text { Ölçüm Değer Yeterliliği }\end{array}$ &, 894 \\
\hline \multirow{3}{*}{ Bartlett Küresellik Testi } & Ki-Kare & 3055,648 \\
& df & 78 \\
& Sig. & 0,000 \\
\hline
\end{tabular}

Tablo 3'te görüldüğü üzere, Sinırsız Kariyer Tutumu için yapılan faktör analizinde KMO değeri 0,894 olarak hesaplanmıştır. Buna göre örneklem sayısı faktör analizi için uygundur (KMO>0,500). Bartlett testi kapsaminda 3055,648 olarak hesaplanan X2 değeri istatistiksel açıdan anlamlı bulunmuştur $(p<0,05)$. KMO ve Bartlett testi sonucuna göre verilerin faktör analizi için uygun olduğu sonucuna ulaşılmıştır. Sınırsız Kariyer Tutumu için faktör analizi sonuçları Tablo 4'te yer almaktadir.

$\mathrm{Bu}$ bulgular, Sınırsız Kariyer Ölçeği'nde yer alan maddelerin orjinaliyle aynı faktör dağılımına sahip olduğunu göstermektedir. Sinırsız kariyer tutumunun iki boyutu birlikte varyansın yüzde

Tablo 2: Çok Yönlü Kariyer Tutumu için Faktör Analizi Sonuçları

\begin{tabular}{|c|c|c|c|c|}
\hline Boyut & Madde & Faktör Yükü & Açık.Varyans Oranı & Cronbach Alfa \\
\hline \multirow{7}{*}{ Değerlerine Göre Hareket Etme } & Madde3 & ,762 & \multirow{7}{*}{28,317} & \multirow{7}{*}{822} \\
\hline & Madde4 &, 752 & & \\
\hline & Madde6 & ,749 & & \\
\hline & Madde5 &, 711 & & \\
\hline & Madde1 & ,636 & & \\
\hline & Madde2 & ,433 & & \\
\hline & Madde7 & ,398 & & \\
\hline \multirow{6}{*}{ Kendi Kendini Yönetme } & Madde 13 & ,836 & \multirow{6}{*}{25,344} & \multirow{6}{*}{, 839} \\
\hline & Madde11 & ,799 & & \\
\hline & Madde12 &, 762 & & \\
\hline & Madde 10 &, 582 & & \\
\hline & Madde8 &, 575 & & \\
\hline & Madde9 & 440 & & \\
\hline
\end{tabular}


Tablo 4: Sınırsız Kariyer Tutumu için Faktör Analizi Sonuçları

\begin{tabular}{|c|c|c|c|c|}
\hline Boyut & Madde & Faktör Yükü & Açık.Varyans Oranı & Cronbach Alfa \\
\hline \multirow{8}{*}{ Psikolojik Hareketlilik } & Madde 19 & 913 & \multirow{8}{*}{43,219} & \multirow{8}{*}{, 936} \\
\hline & Madde 18 & ,908 & & \\
\hline & Madde 16 &, 898 & & \\
\hline & Madde15 &, 865 & & \\
\hline & Madde 17 &, 854 & & \\
\hline & Madde21 &, 784 & & \\
\hline & Madde20 & ,739 & & \\
\hline & Madde 14 & ,688 & & \\
\hline \multirow{5}{*}{ Fiziksel Hareketlilik } & Madde24 & ,893 & \multirow{5}{*}{26,916} & \multirow{5}{*}{891} \\
\hline & Madde25 & 858 & & \\
\hline & Madde23 & 842 & & \\
\hline & Madde26 &, 810 & & \\
\hline & Madde22 &, 758 & & \\
\hline
\end{tabular}

70,13'ünü açıklamaktadır. Cronbach Alfa güvenirlik katsayıları ise Psikolojik Hareketlilik için 0,936 ve Fiziksel Hareketlilik için 0,891 olarak bulunmuştur.

Katılımcıların nevrotiklik, dişadönüklük, uzlaşılabilirlik, özdisiplin ve deneyime açıklık özelliklerini ölçmek için John, Donahue ve Kentle (1991) ile Benet-Martínez ve John (1998) tarafından geliştirilen 44 maddelik Beş Faktör Kişilik Envanteri kullanılmıştır. Envanterin Türkçe'ye uyarlanması, Schmitt ve arkadaşları (2007) tarafindan 56 ülkede gerçekleştirilen bir çalışmanın Türkiye ayağı kapsamında, Sümer ve Sümer (2005) tarafından gerçekleştirilmiştir. Ölçeğin Cronbach Alfa güvenilirlik değerleri nevrotiklik için 0,79 ; dişadönüklük için 0,77 ; deneyime açıklık için 0,76; uzlaşılabilirlik için 0,70 ve özdisiplin için 0,78 olarak bulunmuştur (Schmitt vd., 2007). Beş Faktör Kişilik Envanteri'nin bu çalışma kapsamındaki geçerlilik ve güvenirlik analizleri aşağıda yer almaktadır.

Tablo 5: Beş Faktör Kişilik Envanteri için KMO ve Bartlett Testi Sonuçları

\begin{tabular}{llr}
\hline $\begin{array}{l}\text { Kaiser-Meyer-Olkin (KMO) Örneklem Ölçüm } \\
\text { Değer Yeterliliği }\end{array}$ &, 869 \\
\hline \multirow{3}{*}{ Bartlett Küresellik Testi } & Ki-Kare & 6897,399 \\
& df & 946 \\
& Sig. & 0,000 \\
\hline
\end{tabular}

Tablo 5'te görüldüğü üzere, Beş Faktör Kişilik Envanteri için yapılan faktör analizinde KMO değeri 0,869 olarak hesaplanmıştır. Buna göre örneklem sayısı faktör analizi için uygundur (KMO>0,500). Bartlett testi kapsaminda 6897,399 olarak hesaplanan X2 değeri istatistiksel açıdan anlamlı bulunmuştur $(\mathrm{p}<0,05)$. KMO ve Bartlett testi sonuçlarına göre verilerin faktör analizi için uygun olduğu sonucuna ulaşılmıştır. Beş faktör kişilik envanterinin faktör analizi sonuçları Tablo 6'da yer almaktadir.

Analiz sonuçlarından, Beş Faktör Kişilik Envanteri'nde yer alan maddelerin orjinaliyle aynı faktör dağılımını gösterdiği anlaşılmakadır. Beş faktör kişilik özellikleri, toplam varyansın yüzde 51,62'sini açıklamaktadır. Cronbach Alfa güvenilirlik katsayıları ise Dışadönüklük için 0,881 ; Uzlaşılabilirlik için 0,747; Özdisiplin için 0,814; Nevrotiklik için 0,865 ve Deneyime açıklık için 0,875 olarak bulunmuştur.

\subsection{Verilerin Analizinde Kullanılan İstatistiksel Teknikler}

Toplanan verilerin analizi SPSS 21 programı ile yapılmış ve $\% 95$ güven düzeyi ile çalışılmıştır.

Maddeler için ölçeklerden elde edilen basıklık ve çarpıklık değerlerinin +3 ile -3 arasında olması normal dağılım için yeterli görülmektedir (De Carlo, 1997; Groeneveld ve Meeden, 1984; Hopkins ve Weeks, 1990). Çalışmadaki basıklık ve çarpıklık değerleri 0,84 ile $-0,75$ arasında değişmektedir. $\mathrm{Bu}$ nedenle çok yönlü ve sinırsız kariyer tutumları ile kişilik özellikleri puanlarının normal dağıldıkları kabul edilmiştir. 
Tablo 6: Beş Faktör Kişilik Envanteri için Faktör Analizi Sonuçları

\begin{tabular}{|c|c|c|c|c|}
\hline Boyut & Madde & Faktör Yükü & Açık. Varyans Oranı & Cronbach Alfa \\
\hline \multirow{10}{*}{ Deneyime Açıklık } & Madde25 & 820 & \multirow{10}{*}{15,361} & \multirow{10}{*}{,875 } \\
\hline & Madde15 & 809 & & \\
\hline & Madde20 &, 803 & & \\
\hline & Madde40 &, 736 & & \\
\hline & Madde5 &, 722 & & \\
\hline & Madde10 & ,664 & & \\
\hline & Madde 30 &, 561 & & \\
\hline & Madde44 &, 542 & & \\
\hline & Madde 35 & ,432 & & \\
\hline & Madde41 &, 360 & & \\
\hline \multirow{8}{*}{ Nevrotiklik } & Madde 9 & ,746 & \multirow{8}{*}{10,032} & \multirow{8}{*}{, 865} \\
\hline & Madde14 & ,729 & & \\
\hline & Madde19 &, 725 & & \\
\hline & Madde24 &, 703 & & \\
\hline & Madde 34 & 698 & & \\
\hline & Madde29 & ,686 & & \\
\hline & Madde4 & 635 & & \\
\hline & Madde 39 & ,621 & & \\
\hline \multirow{8}{*}{ Dışadönüklük } & Madde21 & ,742 & \multirow{8}{*}{9,588} & \multirow{8}{*}{,881 } \\
\hline & Madde6 & 694 & & \\
\hline & Madde26 & 661 & & \\
\hline & Madde31 & 619 & & \\
\hline & Madde1 & ,618 & & \\
\hline & Madde 36 & 615 & & \\
\hline & Maddel1 &, 427 & & \\
\hline & Madde 16 & 412 & & \\
\hline \multirow{9}{*}{ Özdisiplin } & Madde23 & ,708 & \multirow{9}{*}{8,469} & \multirow{9}{*}{, 814} \\
\hline & Madde18 & 699 & & \\
\hline & Madde28 & 658 & & \\
\hline & Madde 38 & 633 & & \\
\hline & Madde8 & 633 & & \\
\hline & Madde3 &, 594 & & \\
\hline & Madde43 &, 586 & & \\
\hline & Madde 33 & ,443 & & \\
\hline & Madde13 &, 326 & & \\
\hline \multirow{9}{*}{ Uzlaşılabilirlik } & Madde17 & ,708 & \multirow{9}{*}{8,170} & \multirow{9}{*}{,747 } \\
\hline & Madde 32 & 692 & & \\
\hline & Madde22 & 682 & & \\
\hline & Madde27 & ,626 & & \\
\hline & Madde7 &, 574 & & \\
\hline & Madde42 & ,459 & & \\
\hline & Madde 37 & ,432 & & \\
\hline & Madde2 & ,402 & & \\
\hline & Madde12 &, 347 & & \\
\hline
\end{tabular}

Beş faktör kişilik özellikleri (dişadönüklük, uzlaşılabilirlik, özdisiplin, nevrotiklik, deneyime açıklık) ve demografik özellikler (yaş, son iş yerindeki çalışma süresi, çalışma hayatındaki toplam deneyim yılı) ile sınırsız kariyer (psikolojik hareketlilik, fiziksel hareketlilik) ve çok yönlü kariyer (kendi kendini yönetme, değerlerine göre hareket etme) değişkenleri arasındaki ilişkiyi test etmek amacıyla korelasyon analizi (Pearson r) uygulanmıştır. Kişilik özelliklerinin çok yönlü ve sınırsız kariyer tutumlarını yordama gücü ise aşamalı (stepwise) regresyon analizi ile test edilmiştir.

\section{BULGULAR}

4.1. Çok Yönlü ve Sınırsız Kariyer Tutumları ile Kişilik Özellikleri Arasındaki İlişkilere Ait Bulgular

Araştırma kapsamında gerçekleştirilen korelasyon analizi ile kariyer tutumları ve beş faktör kişilik özellikleri arasındaki ilişki incelenmiştir. Sonuçlar Tablo 7'de yer almaktadır. 
Tablo 7: Kariyer Tutumları ve Kişilik Özellikleri Arasındaki İlişkiler

\begin{tabular}{|c|c|c|c|c|c|c|}
\hline & $\begin{array}{c}\text { Çok Yönlü } \\
\text { Kariyer } \\
\text { Tutumu }\end{array}$ & $\begin{array}{l}\text { Kendi } \\
\text { Kendini } \\
\text { Yönetme }\end{array}$ & $\begin{array}{c}\text { Değerlerine } \\
\text { Göre Hareket } \\
\text { Etme }\end{array}$ & $\begin{array}{l}\text { Sinırsız } \\
\text { Kariyer } \\
\text { Tutumu }\end{array}$ & $\begin{array}{c}\text { Fiziksel } \\
\text { Hareketlilik }\end{array}$ & $\begin{array}{c}\text { Psikolojik } \\
\text { Hareketlilik }\end{array}$ \\
\hline Dışadönüklük &, $263^{\circ}$ &, $207^{\circ}$ &, $278^{*}$ &, $359^{*}$ &,$- 114^{*}$ &, $526^{\circ}$ \\
\hline Uzlaşılabilirlik &, $178^{*}$ &, $152^{\circ}$ &, $173^{*}$ &, $228^{*}$ & ,015 &, $263^{*}$ \\
\hline Özdisiplin &, $250^{*}$ &, $242^{\circ}$ &, $205^{*}$ &, 062 &, 020 & 058 \\
\hline Nevrotiklik &,$- 290^{\circ}$ &,$- 260^{\circ}$ &,$- 264^{*}$ &,- 027 &, $175^{\star}$ & $=, 176^{\circ}$ \\
\hline Deneyime Açıklık &, $382^{*}$ &, $327^{\circ}$ &, $369^{\circ}$ & $268^{\circ}$ &,$- 158^{*}$ &, $454^{\circ}$ \\
\hline
\end{tabular}

$p^{*}<0,05$

Korelasyon katsayısının (r) 0,70 - 1,00 arasında olması güçlü/yüksek, 0,30 - 0,70 arasında olması orta, 0,30'dan küçük olması ise zayıf/düşük düzeyde ilişki olarak yorumlanmıştır (Büyüköztürk, 2013). Korelasyon analizi sonuçlarına göre çok yönlü ve sınırsız kariyer tutumları ve alt boyutları ile kişilik özellikleri arasında genellikle zayıf ya da orta düzeyde ilişkiler olduğu görülmektedir.

Tablo 7'den de izlenebileceği gibi "D1şadönüklük” ile "Çok Yönlü Kariyer Tutumu" arasında pozitif yönlü zayıf bir ilişki (r=,263) saptanmıştır. Alt boyutlar incelendiğinde, "Dişadönüklük” ile "Değerlerine Göre Hareket Etme" ve "Kendi Kendini Yönetme" arasında da pozitif yönlü zayıf bir ilişki (sırasıyla $r=, 278 ; \quad r=, 207$ ) olduğu görülmektedir. "Dışadönüklük” ile "Sınırsız Kariyer Tutumu” arasında pozitif yönlü orta düzeyde bir ilişki (r=,359) saptanmıştır. Alt boyutlar incelendiğinde, "Dişadönüklük" ile "Psikolojik Hareketlilik" arasında pozitif yönlü orta düzeyde bir ilişki (r=,526); "Dışadönüklük" ile "Fiziksel Hareketlilik" arasında negatif yönlü zayıf bir ilişki $(r=-, 114)$ olduğu tespit edilmiştir.

"Uzlaşılabilirlik" ile "Çok Yönlü Kariyer Tutumu” arasında pozitif yönlü zayıf bir ilişki $(r=, 178)$ bulunmaktadır. Alt boyutlar incelendiğinde, "Uzlaşılabilirlik" ile "Değerlerine Göre Hareket Etme” ve "Kendi Kendini Yönetme" arasında da pozitif yönlü zayıf bir ilişki (sırasıyla $r=, 173$; $\mathrm{r}=, 152$ ) olduğu görülmektedir. "Uzlaşllabilirlik" ile "Sınırsız Kariyer Tutumu" arasında pozitif yönlü zayıf bir ilişki $(r=, 228)$ olduğu görülmektedir. Alt boyutlar incelendiğinde, "Uzlaşılabilirlik" ile "Psikolojik Hareketlilik" arasında pozitif yönlü zayıf bir ilişki $(\mathrm{r}=, 263)$ olduğu, ancak "Uzlaşılabilirlik" ile "Fiziksel Hareketlilik" arasında anlamlı bir ilişki bulunmadığı tespit edilmiştir.

“Özdisiplin” ile “Çok Yönlü Kariyer Tutumu” arasında pozitif yönlü zayıf bir ilişki $(r=, 250)$ saptanmıştır. Alt boyutlar incelendiğinde,
"Özdisiplin" ile "Değerlerine Göre Hareket Etme" ve "Kendi Kendini Yönetme" arasında da pozitif yönlü zayıf bir ilişki (sırasıyla r=,205; r=,242) olduğu bulunmuştur. "Özdisplin” ile "Sınırsız Kariyer Tutumu" ve alt boyutları olan "Fiziksel Hareketlilik" / "Psikolojik Hareketlilik" arasında anlamlı bir ilişki bulunmamıştır.

“Nevrotiklik” ile “Çok Yönlü Kariyer Tutumu” arasında negatif yönlü zayıf bir ilişki $(r=-, 290)$ saptanmıştır. Alt boyutlar incelendiğinde, "Nevrotiklik" ile "Değerlerine Göre Hareket Etme" ve "Kendi Kendini Yönetme" arasında da negatif yönlü bir ilişki (sırasıyla r= -,264; r= -,260) olduğu görülmüştür. "Nevrotiklik" ile "Sınırsız Kariyer Tutumu" arasında anlamlı bir ilişki bulunmamış ancak alt boyutlar açısından incelendiğinde "Nevrotiklik" ile "Psikolojik Hareketlilik" arasında negatif yönlü zayıf bir ilişki $(r=-, 176)$ ve "Fiziksel Hareketlilik" arasında pozitif yönlü zayıf bir ilişki $(\mathrm{r}=, 175)$ saptanmıştır.

"Deneyime Açıklık" ile "Çok Yönlü Kariyer Tutumu" arasında pozitif yönlü orta düzeyde bir ilişki (r=,382) olduğu görülmektedir. Alt boyutlar incelendiğinde, "Deneyime Açıklık" ile "Değerlerine Göre Hareket Etme" ve "Kendi Kendini Yönetme" arasında da pozitif yönlü orta düzeyde bir ilişki (sırasıyla r=,369; $r=, 327$ ) saptanmıştır. "Deneyime Açıklık" ile "Sınırsız Kariyer Tutumu" arasında pozitif yönlü zayıf bir ilişki $(r=, 268)$ saptanmıştır. Alt boyutlar incelendiğinde, "Deneyime Açıklık" ile "Psikolojik Hareketlilik" arasında pozitif yönlü orta düzeyde bir ilişki $(r=, 454)$ ve "Fiziksel Hareketlilik" arasında negatif yönlü zayıf bir ilişki $(r=-, 158)$ olduğu tespit edilmiştir.

\section{1. Çok Yönlü ve Sınırsız Kariyer Tutumları ile Demografik Değişkenler Arasındaki İlişkilere Ait Bulgular}

Çok yönlü ve sınırsız kariyer tutumları ile katılımcının yaşı, son iş yerindeki çalışma süresi ve 
Tablo 8: Kariyer Tutumları ile Demografik Değişkenler Arasındaki İlişkiler

\begin{tabular}{|c|c|c|c|}
\hline & Yaş & $\begin{array}{l}\text { Son İ Y Yerinizdeki } \\
\text { Calış̧a Süreniz }\end{array}$ & $\begin{array}{l}\text { Çalşsma Hayatındaki } \\
\text { Toplam Süreniz }\end{array}$ \\
\hline Çok Yönlü Kariyer Tutumu & 091 & 099 & , 108 \\
\hline Kendi Kendini Yönetme &, $114^{\circ}$ &, $123^{*}$ &, $122^{*}$ \\
\hline Değerlerine Göre Hareket Etme &, 040 & 043 &, 065 \\
\hline Simırsız Kariyer Tutumu & ,101 & ,060 &, 061 \\
\hline Fiziksel Hareketlilik &, $144^{\circ}$ &, $144^{*}$ &, $141^{*}$ \\
\hline Psikolojik Hareketlilik & ,004 &,- 046 &,- 042 \\
\hline
\end{tabular}

$\mathrm{p} *<0,05$

çalışma hayatındaki toplam deneyim yılı arasındaki ilişkiyi saptamak üzere yapılan korelasyon analizi sonuçları Tablo 8'de gösterilmektedir.

Kendi Kendini Yönetme” ile "yaş", "son iş yerindeki çalışma süresi" ve "çalışma hayatındaki toplam süre" arasında pozitif yönlü zayıf bir ilişki (sırasıyla $\mathrm{r}=114 ; \mathrm{r}=123 ; \mathrm{r}=122$ ) tespit edilmiştir. Aynı şekilde "Fiziksel Hareketlilik" ile "yaş", "son iş yerindeki çalışma süresi" ve "çalışma hayatındaki toplam süre" arasında pozitif yönlü zayıf bir ilişki (sırasıyla $r=, 144 ; r=144 ; r=141$ ) saptanmıştır.

\subsection{Kariyer Tutumlarını Yordayan Kişilik Özelliklerine Ait İlişkin Bulgular}

Bu bölümde çok yönlü ve sınırsız kariyer tutumları ve alt boyutlarının yordanması için uygulanan aşamalı (stepwise) regresyon analizi sonuçları yer almaktadır. Yordayıcı bir etkisi saptanmayan kişilik boyutları tabloda gösterilmemiştir.

Çok Yönlü Kariyer ve Kişilik. Çok yönlü kariyer tutumu için kişilik özelliklerinin yordayıcı gücüne ilişkin kurulan regresyon modellerinin sınamasına Tablo 9'da yer verilmektedir.
Kurulan modell anlamlıdır $(\mathrm{p}<0,05)$. Model1'e göre "Deneyime Açıklık" özelliği "Çok Yönlü Kariyer Tutumu”nu pozitif yönde etkilemektedir $(B=, 414)$. "Çok Yönlü Kariyer Tutumu”ndaki değişimin \%14,6's1 "Deneyime Açıklık" tarafından açıklanmaktadır.

Kurulan model2 anlamlıdır $(p<0,05)$. Model2'ye göre "Deneyime Açıklık" özelliği "Çok Yönlü Kariyer Tutumu”nu pozitif yönde etkilemekte $(B=, 378)$ iken, "Nevrotiklik" negatif yönde etkilemektedir (B=-,282). "Çok Yönlü Kariyer Tutumu”ndaki değişimin \%20,3’ü “Deneyime Açıklık" ve "Nevrotiklik" tarafından açıklanmaktadır.

Kurulan model3 anlamlıdır $(p<0,05)$. Model3'e göre "Deneyime Açıklık" ve "Özdisiplin" özellikleri “Çok Yönlü Kariyer Tutumu”nu pozitif yönde etkilemekte $(B=, 378 \quad B=, 203)$ iken "Nevrotiklik" negatif yönde etkilemektedir (B=,231). “Çok Yönlü Kariyer Tutumu”ndaki değişimin \%22,4'ü "Deneyime Açıklık", "Nevrotiklik" ve "Özdisiplin" tarafından açıklanmaktadır.

Tablo 9: Çok Yönlü Kariyer Tutumunu Yordayan Kișilik Özellikleri

\begin{tabular}{|c|c|c|c|c|c|c|c|c|}
\hline Model & Bağımlı Değ. & Bağımsız Değ. & $\mathbf{F}$ & $\mathbf{p}$ & B & $\mathbf{t}$ & $\mathbf{p}$ & $\mathbf{R}^{2}$ \\
\hline Model1 & \multirow{6}{*}{$\begin{array}{l}\text { Çok Yönlü } \\
\text { Kariyer } \\
\text { Tutumu }\end{array}$} & $\begin{array}{l}\text { Deneyime } \\
\text { Açıklık }\end{array}$ & 51,834 &, 000 &, 414 & 7,200 &, 000 &, 146 \\
\hline \multirow[t]{2}{*}{ Model2 } & & $\begin{array}{l}\text { Deneyime } \\
\text { Açıklık }\end{array}$ & 38,599 &, 000 &, 378 & 6,729 &, 000 & ,203 \\
\hline & & Nevrotiklik & & &,- 282 & $-4,671$ &, 000 & \\
\hline \multirow{3}{*}{ Model3 } & & $\begin{array}{l}\text { Deneyime } \\
\text { Açıklık }\end{array}$ & & &, 365 & 6,552 &, 000 & \\
\hline & & Nevrotiklik & 29,020 &, 000 &,- 231 & $-3,715$ &, 000 &, 224 \\
\hline & & Özdisiplin & & & ,203 & 2,840 &, 005 & \\
\hline
\end{tabular}


Tablo 10: Değerlerine Göre Hareket Etme Tutumunu Yordayan Kişilik Özellikleri

\begin{tabular}{|c|c|c|c|c|c|c|c|c|}
\hline Model & Bağımlı Değ. & Bağımsız Değ. & $\mathbf{F}$ & $\mathbf{P}$ & B & $\mathbf{t}$ & $\mathbf{p}$ & $\mathbf{R}^{2}$ \\
\hline Model1 & \multirow{5}{*}{$\begin{array}{l}\text { Değerlerine } \\
\text { Göre Hareket } \\
\text { Etme }\end{array}$} & $\begin{array}{l}\text { Deneyime } \\
\text { Açılık }\end{array}$ & 48,013 &, 000 &, 189 & 6,929 & ,000 & , 136 \\
\hline \multirow[t]{2}{*}{ Model2 } & & $\begin{array}{l}\text { Deneyime } \\
\text { Açıklık } \\
\text { Nevrotiklik }\end{array}$ & 33,866 &, 000 & $\begin{array}{l}, 174 \\
-, 120\end{array}$ & $\begin{array}{r}6,474 \\
-4,143\end{array}$ & $\begin{array}{l}, 000 \\
, 000\end{array}$ & , 183 \\
\hline & & $\begin{array}{l}\text { Deneyime } \\
\text { Açıklık }\end{array}$ & & &, 169 & 6,319 &, 000 & \\
\hline \multirow[t]{2}{*}{ Model3 } & & Nevrotiklik & 24,203 &, 000 &,- 102 & $-3,406$ & ,001 & , 194 \\
\hline & & Özdisiplin & & &, 070 & 2,042 &, 042 & \\
\hline
\end{tabular}

Çok Yönlü Kariyer Tutumunun alt boyutu olan "Değerlerine Göre Hareket Etme" için kişilik özelliklerinin yordayıcı gücüne ilişkin kurulan regresyon modellerinin sinamasina Tablo 10'da yer verilmektedir.

Kurulan model1 anlamlıdır $(\mathrm{p}<0,05)$. Model1'e göre "Deneyime Açılık" özelliği "Değerlerine Göre Hareket Etme"yi pozitif yönde etkilemektedir $(B=, 189)$. "Değerlerine Göre Hareket Etme" tutumundaki değişimin \%13,6's1 "Deneyime Açıklık" tarafından açıklanmaktadır.

Kurulan model2 anlamlıdır $(\mathrm{p}<0,05)$. Model2'ye göre "Deneyime Açılık" özelliği "Değerlerine Göre Hareket Etme”yi pozitif yönde etkilemekte $(B=, 189)$ iken "Nevrotiklik" negatif yönde etkilemektedir (B=-,120). "Değerlerine Göre Hareket Etme" tutumundaki değişimin \%18,3'ü "Deneyime Açıklık" ve "Nevrotiklik" tarafindan açıklanmaktadır.

Kurulan model3 anlamlıdır $(p<0,05)$. Model3'e göre "Deneyime Açıklık" ve "Özdisiplin" özellikleri "Değerlerine Göre Hareket Etme”yi pozitif yönde etkilemekte $(B=, 169 ; B=, 070)$ iken "Nevrotiklik" negatif yönde etkilemektedir (B=,102). "Değerlerine Göre Hareket Etme" tutumundaki değişimin \%19,4’ü "Deneyime Açıklık", "Nevrotiklik" ve "Özdisiplin" tarafından açıklanmaktadır.
Çok Yönlü Kariyer Tutumunun diğer alt boyutu "Kendi Kendini Yönetme" için aynı modellemeye dayalı regresyon analizi Tablo 11'de yer almaktadır.

Kurulan model1 anlamlıdır $(\mathrm{p}<0,05)$. Model1'e göre "Deneyime Açıklık" özelliği "Kendi Kendini Yönetme”yi pozitif yönde etkilemektedir (B=,225). "Kendi Kendini Yönetme" tutumundaki değişimin \%10,7'si "Deneyime Açıklık" tarafından açıklanmaktadır.

Kurulan model2 anlamlidir $(\mathrm{p}<0,05)$. Model2'ye göre "Deneyime Açıklık" özelliği "Kendi Kendini Yönetme”yi pozitif yönde etkilemekte $(B=, 204)$ iken "Nevrotiklik" negatif yönde etkilemektedir ( $\mathrm{B}=-, 162)$. "Kendi Kendini Yönetme” tutumundaki değişimin \%15,4'ü "Deneyime Açıklık” ve "Nevrotiklik" tarafından açıklanmaktadır.

Kurulan model3 anlamlıdır $(p<0,05)$. Model3'e göre "Deneyime Açıklık" ve "Özdisiplin" özellikleri “Kendi Kendini Yönetme”yi pozitif yönde etkilemekte $(B=, 196 \quad B=, 133)$ iken "Nevrotiklik" negatif yönde etkilemektedir (B=,129). "Kendi Kendini Yönetme" tutumundaki değişimin \%17,6’sı "Deneyime Açıklık", "Nevrotiklik" ve "Özdisiplin" tarafından açıklanmaktadır.

Tablo 11: Kendi Kendini Yönetme Tutumunu Yordayan Kişilik Özellikleri

\begin{tabular}{|c|c|c|c|c|c|c|c|c|}
\hline Model & Bağımlı Değ. & Bağımsız Değ. & $\mathbf{F}$ & $\mathbf{P}$ & B & $t$ & $\mathbf{p}$ & $\mathbf{R}^{2}$ \\
\hline Model1 & \multirow{5}{*}{$\begin{array}{l}\text { Kendi Kendini } \\
\text { Yönetme }\end{array}$} & $\begin{array}{l}\text { Deneyime } \\
\text { Açılık }\end{array}$ & 36,305 &, 000 &, 225 & 6,025 &, 000 & 107 \\
\hline Model2 & & $\begin{array}{l}\text { Deneyime } \\
\text { Açıklık } \\
\text { Nevrotiklik }\end{array}$ & 27,561 & ,000 &, 204 & 5,557 &, 000 &, 154 \\
\hline \multirow{3}{*}{ Model3 } & & $\begin{array}{l}\text { Deneyime } \\
\text { Açıklık }\end{array}$ & & & , 196 & 5,370 &, 000 & \multirow{3}{*}{, 176} \\
\hline & & Nevrotiklik & 21,491 & ,000 &,- 129 & $-3,174$ &, 002 & \\
\hline & & Özdisiplin & & &, 133 & 2,840 & ,005 & \\
\hline
\end{tabular}


Tablo 12: Sınırsız Kariyer Tutumunu Yordayan Kişilik Özellikleri

\begin{tabular}{lllllllll}
\hline Model & Bağımlı Değ. & Bağımsız Değ. & $\mathbf{F}$ & $\mathbf{p}$ & $\mathbf{B}$ & $\mathbf{t}$ & $\mathbf{p}$ & $\mathbf{R}^{2}$ \\
\hline \multirow{2}{*}{ Model1 } & $\begin{array}{l}\text { Sınırsız } \\
\text { Kariyer } \\
\text { Tutumu }\end{array}$ & Dışadönüklük & 44,997 &, 000 &, 440 & 6,708 &, 000 &, 129 \\
\hline
\end{tabular}

Sinırsız Kariyer Tutumunu Yordayan Kişilik Özellikleri. Sınırsız kariyer tutumu için kişilik özelliklerinin yordayıcı gücüne ilişkin kurulan regresyon modellerinin sinamasina Tablo 12'de yer verilmektedir.

Kurulan model1 anlamlıdır $(\mathrm{p}<0,05)$. Model1'e göre "Dışadönüklük" özelliği "Sınırsız Kariyer Tutumu”nu pozitif yönde etkilemektedir $(B=, 440)$. "Sınırsız Kariyer Tutumu”ndaki değişimin \%12,9’u "Dışadönüklük" tarafından açıklanmaktadır. Diğer kişilik özelliklerinin yordayıcı katkılarının anlamsız olduğu saptanmıştır.

Sinırsiz Kariyer Tutumunun alt boyutu olan "Psikolojik Hareketlilik" için kişilik özelliklerinin yordayıc1 gücüne ilişkin kurulan regresyon modellerinin sinamasina Tablo 13'te yer verilmektedir. etkilemektedir $\quad(\mathrm{B}=, 404 \quad \mathrm{~B}=, 236)$. "Psikolojik Hareketlilik” tutumundaki değişimin \%32'si "Dışadönüklük" ve "Deneyime Açıklık" tarafından açıklanmaktadır.

Sinırsız Kariyer Tutumunun diğer alt boyutu olan "Fiziksel Hareketlilik" için aynı modellemeye dayalı regresyon analizi Tablo 14'te yer almaktadır.

Kurulan modell anlamlıdır $(\mathrm{p}<0,05)$. Modell'e göre "Nevrotiklik" özelliği "Fiziksel Hareketliliği" pozitif yönde etkilemektedir $(B=, 150)$. "Fiziksel Hareketlilik" tutumundaki değişimin "\%3,1'i "Nevrotiklik" tarafından açıklanmaktadır.

Kurulan model2 anlamlidır $(\mathrm{p}<0,05)$. Model2'ye göre "Nevrotiklik" özelliği "Fiziksel Hareketliliği" pozitif yönde etkilemekte $(B=, 134)$ iken "Deneyime Açıklık" negatif yönde etkilemektedir $(B=-, 109)$.

Tablo 13: Psikolojik Hareketlilik Tutumunu Yordayan Kişilik Özellikleri

\begin{tabular}{|c|c|c|c|c|c|c|c|c|}
\hline Model & Bağımlı Değ. & Bağımsız Değ. & $\mathbf{F}$ & $\mathbf{p}$ & B & $t$ & $\mathbf{p}$ & $\mathbf{R}^{2}$ \\
\hline Model1 & \multirow{3}{*}{$\begin{array}{l}\text { Psikolojik } \\
\text { Hareketlilik }\end{array}$} & $\begin{array}{l}\text { Deneyime } \\
\text { Açılık }\end{array}$ & 116,486 &, 000 &, 535 & 10,793 & 000 &, 277 \\
\hline \multirow[b]{2}{*}{ Model2 } & & Dışadönüklük & & & ,404 & 7,121 &, 000 & \multirow[b]{2}{*}{, 320} \\
\hline & & $\begin{array}{l}\text { Deneyime } \\
\text { Açıklık }\end{array}$ & 71,204 &, 000 & ,236 & 4,361 & 000 & \\
\hline
\end{tabular}

Kurulan modell anlamlıdır $(\mathrm{p}<0,05)$. Modell'e göre "Deneyime Açıklık" özelliği "Psikolojik Hareketliliği" pozitif yönde etkilemektedir $(\mathrm{B}=, 535)$. "Psikolojik Hareketlilik" tutumundaki değişimin \%27,7'si "Deneyime Açıklık" tarafından açıklanmaktadır.

Kurulan model2 anlamlidir $(\mathrm{p}<0,05)$. Model2'ye göre "Dışadönüklük" ve "Deneyime Açıklık" özellikleri "Psikolojik Hareketliliği” pozitif yönde
"Fiziksel Hareketlilik" tutumundaki değişimin \%4,9'u "Nevrotiklik" ve "Deneyime Açılılı" tarafından açıklanmaktadır.

Tablo 14: Fiziksel Hareketlilik Tutumunu Yordayan Kişilik Özellikleri

\begin{tabular}{|c|c|c|c|c|c|c|c|c|}
\hline Model & Bağımlı Değ. & Bağımsız Değ. & $\mathbf{F}$ & $\mathbf{p}$ & B & $\mathbf{t}$ & p & $\mathbf{R}^{2}$ \\
\hline Model1 & \multirow{3}{*}{$\begin{array}{l}\text { Fiziksel } \\
\text { Hareketlilik }\end{array}$} & Nevrotiklik & 9,594 & ,002 &, 150 & 3,097 & ,002 & 031 \\
\hline \multirow{2}{*}{ Model2 } & & Nevrotiklik & \multirow{2}{*}{7,809} & \multirow{2}{*}{, 000 } & ,134 & 2,759 & ,006 & \multirow{2}{*}{, 049} \\
\hline & & $\begin{array}{l}\text { Deneyime } \\
\text { Açılık }\end{array}$ & & &,- 109 & $-2,423$ & ,016 & \\
\hline
\end{tabular}




\section{SONUC VE TARTISMA}

$\mathrm{Bu}$ araştırmada sınırsız ve çok yönlü kariyer tutumları, beş faktör kişilik özellikleri açısından incelenmiștir. Değişkenler arası ilişkileri anlamak üzere yapılan korelasyon analizi sonucunda, kariyer tutumları ve kişilik özellikleri arasında zayıf ya da orta düzeyde ilişkiler olduğu saptanmıştır. $\mathrm{Bu}$ da kişilik özelliklerin kadın akademisyenlerin kariyer kararlarını belli ölçüde açıkladığını, ancak bu araştırmanın kapsamı dışındaki farklı değişkenlerin de incelenmesi gerektiğini göstermektedir.

Araştırmada dışadönüklük kişilik özelliği ile çok yönlü ve sinırsız kariyer tutumu arasında pozitif yönlü anlamlı bir ilişki bulunmuştur. Bir başka deyişle dışadönüklük düzeyi arttıkça kadın akademisyenlerin sınırsız ve çok yönlü kariyer tutumunda artı̧̧ olduğu görülmektedir. Costa ve McCrae (1992a), dışadönüklüğün alt boyutlarını sıcakkanlılık, girişkenlik, kendine güven duyma, atak olma, heyecan arama ve olumlu duygulanım olarak belirtmiştir. Bu özelliklere sahip bireylerin dinamik ve aktif olmayı gerektiren yeni kariyer tutumlarını sergilemesi olağan görünmektedir. Dışadönüklük ile sınırsız kariyerin alt boyutu olan psikolojik hareketlilik arasındaki pozitif yönlü ilişki, akademisyen kadınların zihinlerinde sınırsızlık düşüncesinin olduğunu, kendilerini kariyer ya da iş değişikliği yapabilecek güçte hissettiklerini ortaya koymaktadır. Bununla birlikte dışadönüklük ile sınırsız kariyerin diğer alt boyutu olan fiziksel hareketlilik arasında negatif yönlü bir ilişki olduğu tespit edilmiştir. $\mathrm{Bu}$ sonuca göre dışadönüklük düzeyi arttıkça iş veya sektör değiştirme, işten ayrılma gibi fiziksel kariyer hareketleri azalmaktadır. $\mathrm{Bu}$ bulgunun, katılımcıların akademisyen olmalarıyla ilgili olduğu söylenebilir. Akademik kadroyu bırakmadan sosyal bağlantıları çeşitlendirme fikri bu kesimde daha güçlü olabilmektedir. $\mathrm{Bu}$ sonuç, dişadönük erkeklerin tersine dışadönük kadınların iş yerlerinde daha kalıcı olduklarını ortaya koyan Leong ve Boyle'un (1997) araştırma bulgularını desteklemektedir.

Katılımcıların uzlaşılabilirlik düzeyi arttıkça yeni kariyer tutumlarını daha çok sergiledikleri, ancak bu ilişkinin kuvvetli olmadığı görülmektedir. Bilindiği gibi uzlaşılabilirlik özelliği güçlü bir performans yordayıcısı olmadığından (Rothmann ve Coetzer, 2003; Salgado, 1997), kadın akademisyenlerde işbirliğine yatkınlığın bazı özel durumlarda kariyer tutumunu etkilemesi söz konusu olsa da, bu açıdan güçlü bir belirleyicilik sağlamaması şaşırtıcı değildir. Bununla birlikte uzlașılabilirlik kișilik özelliği ile sınırsız kariyerin alt boyutu olan fiziksel hareketlilik arasında anlamlı bir ilişki saptanmamıştır. $\mathrm{O}$ halde uyumlu davranma eğilimi bazen mevcut pozisyonun korunmasına da neden olabilmektedir.

Özdisiplin ile çok yönlü kariyer tutumu ve alt boyutları arasında pozitif yönlü bir ilișki saptanmıștır. Bununla birlikte Costa ve McCrae'nin (1992a) tanımından yola çıkarak özdisiplin ile çok yönlü kariyerin alt boyutu olan kendi kendini yönetme arasında daha güçlü bir ilişkinin tespit edilmemesi şaşırtıcıdır. Dahası, araştırmada özdisiplin ile sınırsız kariyer tutumu, fiziksel hareketlilik ve psikolojik hareketlilik arasında hiçbir anlamlı ilişki tespit edilmemiștir. Oysa özdisiplin, çoğu zaman kariyer yaşamı ile en çok ilişkilendirilen kişilik özelliğidir. Özdisiplin ile ilgili araştırmalara (Barrick ve Mount, 1991; Katic vd., 2017; Robbins ve Judge, 2013; Sutin vd., 2009; Zimmerman, 2008) rağmen, sunulan bu araștırmada özdisiplin ile sinırsız kariyer tutumu ve alt boyutları arasında anlamlı bir ilişkinin saptanmamıs olması ilginç görünmektedir. Bu bulgu, özdisiplin kişilik özelliğinin katılımcılar için başat kriter olmasına bağlanabilir. Bilhassa akademik camiada var olabilmek tam da beş faktör kişilik modelinde ifade edildiği gibi, sorumluluklarını yerine getirme, yoğun ve uzun soluklu çalışmalara istekli olma ve yılmama gibi yüksek özdisiplin düzeyinin yansımalarını gerektirmektedir. Diğer bir ifadeyle, özdisiplin kişilik özelliğinin çalışmada yer alan kadın akademisyenlerin büyük çoğunluğu için gelişkin düzeyde olduğu düşünülmektedir. $\mathrm{O}$ nedenle, düşük ya da yüksek özdisiplin seviyesi kariyer kararları açısından belirleyici olmaktan uzak kabul edilebilir.

Nevrotiklik ile çok yönlü kariyer tutumu ve alt boyutları arasında negatif yönlü anlamlı bir ilişkinin saptanması önceki çalışmaları (Hirschi vd., 2011; Martincin ve Stead, 2015) desteklemektedir çünkü yüksek nevrotiklik düzeyi, bireyin kayg, depresyon, öfke, anlık değișen ruh hali gibi olumsuz duygular içinde olmasını ifade etmektedir. $\mathrm{Bu}$ özellikler ise bireyin bağımsız hareket etmesini, kariyerini planlamasını ve kendi kendini yönetmesini zorlaștırmaktadır. Sınırsız kariyerin alt boyutları açısından incelendiğinde, nevrotiklik ile psikolojik hareketlilik arasında negatif; nevrotiklik ile fiziksel hareketlilik arasında ise pozitif bir ilişki saptanmıştır. Elde edilen sonuçlar önceki araştırmaları (Bruk-Lee vd., 2009; Judge ve Ilies, 2002; Zimmerman, 2008) desteklemektedir. Nevrotiklik düzeyi yükseldikçe işten ayrılma gibi fiziksel hareketlerin artmasi da bu anlamda tutarlıdır. Bununla birlikte nevrotiklik düzeyi arttıkça bireyin iş yerinin sınırlarını aşabileceğine dair algısının ve inancının zayıflayacağı, buna bağlı olarak psikolojik hareketlilik düzeyinin azalacağı sonucu da anlamlı görünmektedir. 
Deneyime açıklık ile çok yönlü kariyer tutumu ve alt boyutları arasında pozitif yönlü bir ilişkinin tespit edilmesi deneyime açı bireylerin kariyerlerinde daha bağımsız hareket ettiklerini, yeniliklere açık olduklarını, kişisel değerlerine ve önceliklerine göre kararlar aldıklarını göstermektedir. Bu bulgular, Hogan ve Holland'ın (2003) araştırma sonuçlarını desteklemektedir. Deneyime açıklık ile sınırsız kariyer tutumu ve alt boyutu olan psikolojik hareketlilik arasinda ise pozitif yönlü bir ilişki saptanmıştır. Buna göre deneyime açık kişiler sınırsız bir kariyere sahip olabileceklerine, farklı seçenekleri değerlendirebileceklerine dair bir algıya sahiptirler. Bu bulgu, deneyime açık kişilerin kalıpların dışında hareket edebilme, esnek düşünme, yeniliğe açık olma özellikleri nedeniyle anlamlı görünmektedir. Bununla birlikte deneyime açıklık ile sınırsız kariyerin diğer alt boyutu olan fiziksel hareketlilik arasında negatif yönlü bir ilişki saptanmıştır. Bir başka ifadeyle, deneyime açıklık arttıkça bireylerin işten ayrilma ve benzeri fiziksel hareketliliği azalmaktadır. Oysa yapılan bazı çalışmalar (Choi vd., 2015; Dragoni vd., 2011) deneyime açık ve proaktif yapıdaki bireylerin yeniliğe ve değişime duydukları ihtiyaç nedeniyle özellikle organizasyon dışındaki kariyer alternatiflerini tercih etmeyi ve mevcut iş yerlerinden ayrılmayı göze aldıklarını ortaya koymuştur. $\mathrm{Bu}$ yapıdaki kişiler yeni bir organizasyonu, farklı bir işi mevcut işlerine tercih edebilmektedirler. Sonucun bu şekilde çıkması, çalışma grubunun akademik kadrolarda çalışan kadınlardan oluşması ve bu kadınların deneyime açık olsalar dahi fiziksel bir hareketlilik tercih etmedikleri biçiminde yorumlanabilir. Bu kadınlar sahip oldukları akademik pozisyonlar nedeniyle çeşitli ve zengin kariyer deneyimleri yaşamakta, yeni insanlarla tanışmakta, farklı projelerde yer almakta, dolayısıyla kurumlarından ayrılmayı gerektirecek bir fiziksel hareketliliğe istek duymamaktadırlar. Bazı demografik özellikler ile kariyer tutumları arasındaki ilişki incelendiğinde, katılımcıların yaşı, son iş yerindeki çalışma süreleri ve iş hayatındaki toplam deneyim süreleri arttıkça kendi kendilerini yönetme ve fiziksel hareketlilik düzeylerinin arttığı görülmektedir. Akademik hayatta y1llar içinde deneyim kazanan ve daha da donanımlı hale gelen kadın akademisyenler buna bağlı olarak özerk hareket etmeye yatkın olabilmektedirler. Bununla birlikte bu ilişkilerin zayıf olduğu ve toplam puan açısından anlamlı korelasyonlar gözlenmediği düşünülmektedir.

Aşamalı regresyon analizi sonuçlarına göre deneyime açıklık ve özdisiplin kişilik boyutları çok yönlü kariyer tutumunu pozitif yönde; nevrotiklik kişilik boyutu ise negatif yönde yordamaktadır. Kendi kendini yönetme ve değerlerine göre hareket etme alt boyutları için de aynı kişilik özelliklerinin yordayıcı oldukları saptanmıştır. Bu sonuç Hall'ın (1976) çok yönlü kariyeri tanımlarken kullandığı "gelişim ve özgürlük ihtiyacının ön planda olduğu, bireyin kariyerini kendisinin yönettiği, hareketlilik seviyesinin yüksek olduğu" şeklindeki ifadeler ile tutarlı görünmektedir çünkü bu özellikler kişiliğin deneyime açılık boyutu ile örtüşmektedir. Elde edilen sonuçlar Hogan ve Holland'in (2003) bulguları ile paralellik göstermektedir. Buna ek olarak, yeni kariyer modellerinde bireyin pek çok konuyu kendisinin düşünerek planlaması gerekmektedir (Sullivan, 1999). "Kendi kendini yönetme” ancak özdisiplin sayesinde gerçekleşebilmektedir. Özdisiplin sahibi bireyler etkili problem çözme, çevreden yardım alma ve olumlu düşünerek sorunlarla başa çıkma becerilerini kullanmaktadırlar (Connor-Smith vd., 2007). Bu nedenlerden ötürü özdisiplin kişilik özelliğinin çok yönlü kariyer tutumunu yordaması tutarlı görünmektedir. Önceki bölümlerde sıkça değinildiği gibi nevrotiklik kariyer yaşamındaki pek çok konu (iş tatmini, performans, işten ayrılma...) ile ilişkilendirilmektedir. Duygusal dengeye sahip olmak, sağlıklı kararlar alarak uygulayabilmek açısından kritik bir öneme sahiptir. Bu nedenle nevrotikliğin çok yönlü kariyer tutumunu ve alt boyutlarını negatif yönde yordaması anlamlı görünmektedir. Kadın akademisyenlerin nevrotik özellikleri baskınlaştıkça farklı bir kariyer planı yapma, yaşamları üzerinde kontrol sahibi olma ve değerlerine göre hareket etme eğilimleri zayıflamaktadır.

Kişilik özelliklerinin sınırsız kariyer tutumunu yordama durumu incelendiğinde dişadönüklüğün etkili olduğu görülmektedir. Costa ve McCrae (1992b), dişadönüklügün alt boyutlarını sıcakkanlılık, girişkenlik, kendine güven duyma, atak olma, heyecan arama ve olumlu duygulanım olarak belirtmiştir. Bu özellikler sınırsız kariyerin açılımı ile (kariyer yönetiminde sorumluluk alma, çok sayıda örgütte çalışma, işin psikolojik olarak anlamlı olması vb.) ilişkili görünmektedir. Dışadönüklüğün aynı zamanda sınırsız kariyerin alt boyutu olan psikolojik hareketliliği yordadığ 1 da bulunmuştur. Bununla birlikte psikolojik hareketliliği pozitif yönde etkileyen en önemli boyut deneyime açıklıktır. Bu boyut tek başına psikolojik hareketlilikteki değişimin \%27,7'sini açılamaktadır. Deneyime açı olan bireylerin yeniliğe ve değişime duydukları ihtiyaç nedeniyle özellikle organizasyon dışındaki kariyer alternatiflerini tercih etme ve mevcut iş yerlerinden ayrılmayı göze alma durumları olabilmektedir (Choi vd., 2015). Ancak araştırmada elde edilen ilginç sonuçlardan bir tanesi, deneyime açıklık özelliğinin sinırsız kariyerin diğer alt boyutu olan fiziksel hareketliliği düşük bir yüzdeyle da olsa negatif yönde yordamasıdır. Deneyime açıklık arttıkça 
fiziksel hareketlilik (kariyer/meslek değişikliği, örgüt değişikliği, çalışma biçimi değişikliği vb.) azalmaktadır. Bunun nedeninin, yine araştırmanın akademik kadrolarda çalışan kadınları kapsaması olduğu düşünülmektedir. $\mathrm{Bu}$ kadınlar deneyime açık bir kişiliğe sahip olsalar da bağlı oldukları akademik kurumlarda ve yaptıkları işlerde farklı deneyimler yaşayabildikleri için fiziksel olarak hareket etmeyi seçmemektedirler. Akademinin çalışma koşullarının bağımsızlığa imkan tanıması sebebiyle, akademisyenlerin zaman yönetimi, ders içeriği, araştırma alanları gibi konularda kontrol sahibi olmaları, onları farklı bir katılımcı grubu haline getirmektedir. Dolayısıyla bu kadınlar, fiziksel hareketlilik yerine bulundukları yerde güçlü bir kariyer ilerlemesi gerçekleştirmeyi ve ilgi alanlarını koruyarak zenginleştirmeyi tercih etmektedirler. Fiziksel hareketliliği pozitif yönde yordayan tek kişilik özelliği nevrotikliktir. Nevrotiklik, fiziksel hareketlilikteki değişimin sadece \%3'ünden sorumlu olsa $\mathrm{da}$, bu sonuç nevrotik bireylerin işten ayrılma sıklığının arttığını gösteren literatürdeki benzer çalışmalarla (Cropanzano vd., 1993; Zimmerman, 2008) tutarlıdır. $\mathrm{Bu}$ oranın düşük olması yine akademisyenlik mesleğine ait özgün iş yapma koşullarıyla açıklanabilir. Araştırmadaki kadınlar nevrotiklik kişilik özelliğine sahip olsalar dahi, işlerinden fiziksel olarak ayrılmayı tercih etmemektedirler.

Literatürde yeni kariyer tutumları ile kişilik özelliklerini inceleyen sınırlı sayıda çalışma bulunmaktadır. Sunulan çalışma, bu konuya odaklanarak kadın akademisyenlerin kariyer kararlarına 1 şık tutmayı amaçlamıştır. Bununla birlikte çalışmanın çeşitli sınırlılıkları da bulunmaktadır. Araştırma öz-raporlama (selfreport) yöntemine dayandığından, katılımcıların kişisel farkındalık düzeyleri ve verdikleri cevapların doğruluk derecesi kesin biçimde ölçülememektedir. Buna ek olarak, elde edilen sonuçlar Ankara ilindeki altı üniversitelerde çalışan 306 kadın akademisyenle sinırlı olduğundan, daha genellenebilir sonuçlara ulaşmak için farklı illeri, sektörleri ve daha geniş örneklem gruplarını kapsayan benzer araştırmaların yapılması önerilmektedir. Buna ek olarak çalışmanın erkek katılımcılarla da gerçekleştirilerek sonuçların karşılaştırılmasının alan yazına hatırı sayılır bir katkı sağlayacağ 1 da düşünülmektedir.

\section{ETÍK BEYANATI}

Destek Bilgisi: Bu çalışma, kamu, ticari veya kar amacı gütmeyen kuruluşlar gibi herhangi bir organizasyondan destek almamıștır.

Çıkar Çatışması: Tüm yazarlar adına, sorumlu yazar çıkar çatışması olmadığını belirtir.

Etik Onay: İnsan katılımcıları içeren çalışmalarda gerçekleştirilen tüm prosedürler, kurumsal ve / veya ulusal araștırma komitesinin etik standartlarına ve 1964 Helsinki deklarasyonuna ve daha sonraki değişikliklerine veya karşılaştırılabilir etik standartlara uygundur.

Bilgilendirilmiş Onam Formu: Çalışmaya katılan tüm bireysel katılımcılardan bilgilendirilmiş onam formu alınmıştır. 


\section{KAYNAKÇA}

Arthur, M. B. (1994). The boundaryless career: A new perspective for organizational inquiry. Journal of Organizational Behavior, 15, 295-306.

Arthur, M. B. \& Rousseau, D. M. (1996). The boundaryless career: A new employment principle for a new organizational era. New York: Oxford University Press.

Barrick, M. R. \& Mount, M. K. (1991). The big five personality dimensions and job performance: A metaanalysis. Personnel Psychology, 44, 1-26.

Baruch, Y. (2014). The development and validation of a measure for protean career orientation. The International Journal of Human Resource Management, 25(19), 2702-2723.

Baruch, Y. \& Hall, D. T. (2004). Preface for the JVB special issue on careeers in academia. Journal of Vocational Behaviour, 64, 237-240.

Benet-Martinez, V. \& John, O. P. (1998). Los Cinco Grandes across cultures and ethnic groups: Multitraitmultimethod analyses of the Big Five in Spanish and English. Journal of Personality and Social Psychology, 75, 729-750.

Bianchi, S. M., Robinson, J. P. \& Milkie, M. A. (2006). Changing rhythms of American family life. New York: Russell Sage Foundation.

Biemann, T., Zacher, H., \& Feldman, D. C. (2012). Career patterns: A twenty-year panel study. Journal of Vocational Behavior, 81(2), 159-170.

Briscoe, J. P. \& Hall, D. T. (2006). The interplay of Boundaryless and Protean careers: Combinations and implications. Journal of Vocational Behavior, 69, 418.

Briscoe, J. P., Hall, D. T. \& DeMuth, R. L. F. (2006). Protean and Boundaryless careers an empirical exploration. Journal of Vocational Behavior, 69, 30-47.

Brown, S. D. \& Hirschi, A. (2013). Personality, career development, and occupational attainment. In S. D. Brown \& R. W. Lent (Eds.), Career development and counseling: Putting theory and research to work. (pp. 299-328). Hoboken, NJ: Wiley \& Sons Inc.

Bruk-Lee, V., Khoury, H. A., Nixon, A. E., Goh, A., \& Spector, P. E. (2009). Replicating and extending past personality/job satisfaction meta-analyses. Human Performance, 22(2), 156-189.

Burger, J. (2006). Kişilik. İstanbul: Kaknüs Yayınları.

Büyüköztürk, Ş. (2013). Sosyal bilimler için veri analizi el kitabr (10. Basım). Ankara: Pegem Akademi Yayıncilık.

Cabrera, E. F. (2007). Opting out and opting in: understanding the complexities of women's career transitions. Career Development International, 12(3), 218-237.

Choi, D., Oh, I. \& Colbert, A. E. (2015). Understanding organizational commitment: a meta-analytic examination of the roles of the five-factor model of personality and culture. Journal of Applied Psychology, 100(5), 1542-1567.

Connor-Smith, J. K. \& Flachsbart, C. (2007). Relations between personality and coping: A metaanalysis. Journal of Personality and Social Psychology, 93(6), 1080-1107.

Costa, P. T. Jr. \& McCrae, R. R. (1992a). Four ways five factors are basic. Personality and Individual Differences, 13(6), 653-665.

Costa, P. T. Jr. \& McCrae, R. R. (1992b). Revised NEO Personality Inventory (NEO-PI-R) and NEO FiveFactor Inventory (NEO-FFI) professional manual. Odessa, FL: Psychological Assessment Resources.

Cropanzano, R., James, K. \& Konovsky, M. A. (1993). Dispositional affectivity as a predictor of work attitudes and job performance. Journal of Organizational Behavior, 14, 595-600.

Çakmak-Otluoğlu, K. Ö. (2018). Kariyerin Değişen Kuralları. Ankara: Nobel Akademik.

De Carlo, L.T. (1997). On the meaning and use of Kurtosis. Psychological Methods, 2, 292-307.

DeFillippi, R. J. \& Arthur, M. B. (1994). The boundaryless career: a competency-based prospective. Journal of Organizational Behavior, 15(4), 307-324.

DeNeve, K. M., \& Cooper, H. (1998). The happy personality: A meta-analysis of 137 personality traits and subjective well-being. Psychological Bulletin, 124, 197-229.

Dragoni, L., Oh, I.-S., Vankatwyk, P. \& Tesluk, P. E. (2011). Developing executive leaders: The relative contribution of cognitive ability, personality, and the accumulation of work experience in predicting strategic thinking competency. Personnel Psychology, 64, 829-864

Groeneveld, R.A. \& Meeden, G. (1984) Measuring skewness and kurtosis. The Statistician, 33, 391-399.

Hall, D. T. (1976). Careers in organizations. Glenview, IL: Scott, Foresman.

Hall, D. T. (1996). Protean careers of the 21st century. Academy of Management Executive, 10(4), 8-16.

Hall, D. T. (2004). The Protean career: A quarter-century journey. Journal of Vocational Behavior, 65, 1-13.

Hirschi, A., Niles, S. G. \& Akos, P. (2011). Engagement in adolescent career preparation: Social support, 
personality and the development of choice decidedness and congruence. Journal of Adolescence, 34(1), 173-182

Hogan, J. \& Holland, B. (2003). Using theory to evaluate personality and job-performance relations: A socioanalytic perspective. Journal of Applied Psychology, 88(1), 100-112.

Hopkins, K. D. \& Weeks, D. L. (1990). Tests for normality and measures of skewness and kurtosis: Their place in research reporting. Educational and Psychological Measurement, 50, 717-729.

Houston, D. M. (2005). Personality. In Hewstone, M., Fincham, F. D., \& Foster, J. (Eds.). Psychology. (pp. 292-313). BPS Textbooks in Psychology. Oxford, UK: Blackwell.

John, O. P., Donahue, E. M. \& Kentle, R. L. (1991). The Big Five Inventory-Versions 4a and 54. Berkeley: University of California, Berkeley, Institute of Personality and Social Research.

Judge, T. A., Heller, D. \& Mount, M. K. (2002). Fivefactor model of personality and job satisfaction: A meta-analysis. Journal of Applied Psychology, 87, 530-541.

Judge, T. A., Higgins, C. A., Thoresen, C. J. \& Barrick, M. R. (1999). The Big Five personality traits, general mental ability, and career success across the life span. Personnel Psychology, 52, 621-652.

Judge, T. A. \& Ilies, R. (2002). Relationship of personality to performance motivation: A metaanalytic review. Journal of Applied Psychology, 87(4), 797-807.

Kale, E. \& Özer, S. (2012). İşgörenlerin çok yönlü ve sınırsız kariyer tutumları: Hizmet sektöründe bir araştırma, Eskişsehir Osmangazi Üniversitesi IIIBF Dergisi, 7(2),173-196.

Katic, I., Ivanisevic, A., Grubic-Nesic, L. \& Penezić, N. (2017). Effects of sociodemographic characteristics and personality traits on career development. The International Journal of Aging and Human Development, 87(2), 201-216.

Leong, F. T. L. \& Boyle, K. A. (1997). An individual diff erences approach to midlife career adjustment: An exploratory study. In M. E. Lachman \& J. B. James (Eds.), Multiple paths of midlife development (pp. 411-451). Chicago: The University of Chicago Press.

Mainiero, L. A. \& Sullivan, S. E. (2005). Kaleidoscope careers: An alternate explanation for the "opt-out" revolution. Academy of Management Executive, 19, 106-123.

Martincin, K. M. \& Stead, G. B. (2015). Five-factor model and difficulties in career decision making: A meta-analysis. Journal of Career Assessment, 23, 319.
McCrae, R. R. \& Costa, P. T. Jr. (1987). Validation of the five-factor model of personality across instruments and observers. Journal of Personality and Social Psychology, 52(1), 81-90.

McCrae, R. R. \& Costa, P. T. Jr. (1989). The structure of interpersonal traits: Wiggins's circumplex and the five-factor model. Journal of Personality and Social Psychology, 56(4), 586-595.

McCrae, R. R. \& Costa P. T. Jr. (1997). Personality trait structure as a human universal. American Psychologist, 52(5), 509-516.

McCrae, R. R. \& Costa, P. T. Jr. (1999). A five-factor theory of personality. In L. A. Pervin \& O.P. John (Eds.), Handbook of Personality: Theory and Research (pp. 139-153). New York: Guilford Press.

McCrae, R. R. \& John, O. P. (1992). An introduction to the five-factor model and its applications. Journal of Personality, 60(2), 175-215.

Onay, M. \& Vezneli, Z. (2012). Sınırsız ve çok yönlü kariyer: Akademisyenlerin kariyer yaşamı. Sosyal ve Beşeri Bilimler Dergisi, 4(1), 193-202.

Özkanl1, Ö. \& Korkmaz, A. (2000). Kadın Akademisyenler. AÜ Siyasal Bilgiler Fakültesi Yayını, Yayın No:586.

Paksoy, M., Hırlak, B. \& Balıkçı, O. (2017). Sınırsız ve çok yönlü kariyer tutumlarının bazı demografik özellikler açısından incelenmesi: Adana örneği. International Journal of Academic Value Studies, 3(12), 277-292.

Pervin, L.A., Cervone, D. \& John, O.P. (2005). Personality: theory and research. New York: John Wiley \& Sons, Inc.

Robbins, S. P. \& Judge, T. A. (2013). Organizational Behavior (15th Ed). Boston: Pearson.

Rothmann, S. \& Coetzer, E. P. (2003). The big five personality dimensions and job performance. $S A$ Journal of Industrial Psychology, 29 (1), 68-74.

Salgado, J. F. (1997). The five factor model of personality and job performance in the European Community. Journal of Applied Psychology, 82(1), 30-43.

Schmitt, D. P., Allik, J., McCrae, R. R., Benet-Martínez, V., Alcalay, L. \& Ault, L. (2007). The geographic distribution of Big Five personality traits: Patterns and profiles of human self description across 56 nations. Journal of Cross-Cultural Psychology, 38, 173-212.

Segers, J., Inceoglu, I., Vloeberghs, D., Bartram, D. \& Henderickx, E. (2008). Protean and boundaryless careers: A study on potential motivators. Journal of Vocational Behavior, 73(2), 212-230.

Seymen, O. A. (2004). Geleneksel kariyerden sinırsız ve dinamik/değişken kariyere geçiș: Nedenleri ve 
sonuçları üzerine yazınsal bir inceleme. Uludă̆ Üniversitesi İktisadi ve İdari Bilimler Fakültesi Dergisi, 23(1), 79-114.

Sullivan, S. E. (1999). The changing nature of careers: A review and research agenda. Journal of Management, $25,457-484$.

Sullivan, S. E. \& Arthur, M. B. (2006). The evolution of the boundaryless career concept examining physical and psychological mobility. Journal of Vocational Behavior, 69, 19-29.

Sutin, A. R., Costa, P., Miech, R., \& Eaton, W. W. (2009). Personality and career success: Concurrent and longitudinal relations. European Journal of Personality, 23(2), 71-84.

Suvacı, B. \& Baş, D. P. (2018). Banka çalışanlarının çok yönlü ve sınırsız kariyer tutumları. Çankırı Karatekin Üniversitesi İIBF Dergisi, 8(1), 113-140.

Sümer, N. \& Sümer, H. C. (2005). Beş faktör kişilik özellikleri ölçeği (Yayınlanmamış çalışma).

Valcour, P. M. \& Tolbert, P. S. (2003). Gender, family and career in the era of boundarylessness: Determinants and effects of intra- and interorganizational mobility. International Journal of Human Resource Management, 14(5), 768-787.

Weisberg, Y. J., DeYoung, C. G. \& Hirsh, J. B. (2011). Gender differences in personality across the ten aspects of the big five. Frontiers in Psychology, 2, Article 178.

Wille, B., De Fruyt, F. \& Feys, M. (2010). Vocational interests and Big Five traits as predictors of job instability. Journal of Vocational Behavior, 76, 547558

Wolff, H. G. \& Kim, S. (2012). The relationship between networking behaviors and the big five personality dimensions. The Career Development International, 17(1), 43-66.

Zimmerman, R. D. (2008). Understanding the impact of personality traits on individuals' turnover decisions: A meta-analytic path model. Personnel Psychology, 61, 309-348. 